\title{
Ma-Pi 2 Macrobiotic Diet Intervention in Adults with Type 2 Diabetes Mellitus
}

\author{
Carmen Porrata, MD, PhD, Julio Sánchez, MD, Violeta Correa, MD, Alfredo Abuín, MD, Manuel Hernández-Triana, MD, PhD, \\ Raúl Vilá Dacosta-Calheiros, MD, María Elena Díaz, PhD, Mayelín Mirabal, MS, Eduardo Cabrera, PhD, Concepción Campa, \\ MS, Mario Pianesi
}

\begin{abstract}
Introduction Diet is a cornerstone of comprehensive treatment of diabetes mellitus. The macrobiotic diet is low in fat and rich in dietary fiber, veg etables and whole grains, and therefore may be a good therapeutic option.

Objective Assess the influence of the Ma-Pi 2 macrobiotic diet on physical, hematologic and biochemical variables, as well as on hypoglycemic medication, in adults with type 2 diabetes mellitus.

Materials and Methods A 6-month dietary intervention was carried out in 16 adults with type 2 diabetes mellitus and poor glucide metabolism control (glycosylated hemoglobin, $\mathrm{HbA} 1>8.5 \%$ ) receiving treatment at the Diabetic Care Center in Colón, Matanzas province, Cuba. The diet was prepared and served daily by macrobiotic specialists. Type and amount of food consumed and nutritional content were assessed using a weighted food-consumption survey. At onset and termination of the intervention, anthropometric and body composition variables were measured, as were biochemical (glucide and lipid metabolism) and other nutritional safety variables, and hypoglycemic drug use.
\end{abstract}

Results The diet provided sufficient energy and protein. It was low in fat, high in complex carbohydrates and dietary fiber, and provided

\section{INTRODUCTION}

Diabetes mellitus affects 246 million people in the world and is predicted to reach 380 million by 2030.[1] In Latin America, the number of diabetics is expected to increase more than $50 \%$, from 13.3 million in 2002 to 32.9 million in 2030.[2]

According to the Pan American Health Organization, the "nutritional transition" in Latin America and the Caribbean is characterized by very low intake of vegetables, whole grains and fruits, combined with a relatively high intake of foods rich in saturated fats, sugars and salt, such as milk, meats, refined grains and processed foods.[3] This dietary configuration is a key factor in the development of chronic diseases, particularly diabetes mellitus.

The magnitude of the diabetes mellitus epidemic also may have an impact on economic growth.[4,5] The cost of health care for people with diabetes is 2 to 3 times higher than for non-diabetics. [6] For this reason the American Diabetes Association has called for measures to increase efficacy of prevention, diagnosis and treatment.[7]

Diet is a key factor in both prevention and treatment of type 2 diabetes mellitus. Although dietary recommendations for therapeutic management of diabetes are constantly changing, most follow these general guidelines: restrict the intake of foods with high glycemic index and load; reduce fat intake (especially saturated fats and trans fatty acids) and cholesterol; increase the intake of whole grains and fiber; limit protein and reduce salt.[8-10] Diets low in fat and rich in dietary fiber and whole grains have been adequate amounts of vitamins and minerals, except for vitamin B12. At 6 months, anthropometric variables were significantly lower, lean body mass was preserved, and glucide and lipid metabolism was controlled. All participants were able to eliminate insulin treatment, and $25 \%$ continued treatment with glibenclamide only. Mean total cholesterol, LDL cholesterol and triglyceride values dropped $16.4 \%, 22.7 \%$ and $37.0 \%$, respectively, while mean HDL cholesterol rose $97.8 \%$. Mean glycemia and $\mathrm{HbA} 1$ values also decreased $63.8 \%$ and $54.5 \%$, respectively. According to lipid levels and ratios, cardiovascular risk was also considerably reduced. Hemoglobin, total protein, albumin and creatinin levels indicated that nutritional safety was maintained. There were no adverse events.

Conclusions In the 6-month intervention, the Ma-Pi 2 macrobiotic diet had a positive influence on weight control, body fat, and glucide and lipid metabolism in patients with type 2 diabetes mellitus. Further research is needed to validate these encouraging results, particularly a clinical trial in which a control group receives the standard diet recommended for diabetic patients.

Keywords: Type 2 diabetes mellitus; adult; macrobiotic diet; diet therapy

shown to be effective for maintaining body weight and reducing glycemia and cholesterol levels.[10,11] The macrobiotic diet fulfills these requirements.

Macrobiotics was developed by George Ohsawa, based on two ancient Asian theories (Yin/Yang and the Five Transformations). [12] Mario Pianesi simplified the food regimens proposed by Ohsawa to make them more acceptable in Western cultures. Pianesi proposed 5 "Ma-Pi" diets.[13] The Ma-Pi 2 diet was specifically designed for diabetes mellitus patients, particularly those with metabolic disorders. The results ascribed to it are mainly anecdotal and testimonial but there is growing interest in conducting scientific studies to determine its efficacy. Since 2001, Cuba's Finlay Institute has been studying the nutritional characteristics and safety of the Ma-Pi diets, as well as their therapeutic effect on several chronic diseases, particularly type 2 diabetes mellitus.[14-16] These studies are part of an international multicenter project sponsored by the Italian organization Un Punto Macrobiotico (UPM), with research also being conducted in Thailand,[17] Ivory Coast and China.

Given the positive results yielded by these studies and the serious epidemiological profile presented by diabetes mellitus, the Finlay Institute proposed an intervention using the Ma-Pi 2 diet in a group of adults with type 2 diabetes mellitus receiving treatment at the Diabetic Care Center (CAD, its Spanish acronym) in Colón, Matanzas province. CADs have been established by the Cuban Ministry of Public Health (MINSAP, its Spanish acronym) in every province to provide specialized services for all diabetic patients, 
Ma-Pi 2 Diet Typical Composition

Food* (Source) $\quad$ Grams Per Person Per Day

Brown rice (MINAGRI, Cuba) 350

Husked barley (La Salvia, Italy) 25

Millet (La Salvia, Italy) 25

Chicory (Urban Agriculture, Cuba) 50

Broccoli (Urban Agriculture, Cuba) 100

Onion (MINAGRI, Cuba) 200

Kale (Urban Agriculture, Cuba) 100

Parsley (Urban Agriculture, Cuba) 10

Radish (Urban Agriculture, Cuba) 40

Carrots (MINAGRI, Cuba) 200

Chickpeas (MINAGRI, Cuba) 30

Black beans (MINAGRI, Cuba) 30

Sesame seeds (Urban Agriculture, 45

Cuba)

Kombu seaweed (La Salvia, Japan) 2

Nori seaweed (La Salvia, Japan) 6

Wakame seaweed (La Salvia, Japan) 2

Miso (La Salvia, Italy) 6

Tamari (La Salvia, Italy) 6

Unrefined sea salt (MINBAS, Cuba)

Bancha tea (La Salvia, Japan)

$1000 \mathrm{ml}$

* Raw food, ready for processing

including consultations with medical specialists, nutritional counseling, medication, health care, and hygiene.

The objective of this study was to evaluate the effects of the Ma$\mathrm{Pi} 2$ diet on physical and body composition variables, glucide and lipid metabolism, nutritional safety (hemoglobin, total protein and albumin levels), and use of insulin and other hypoglycemic medication in a group of adults with type 2 diabetes mellitus and poor glucide metabolism control (high glycosylated hemoglobin).

\section{METHODS}

Type of study and subjects A prospective intervention study with the Ma-Pi 2 diet was conducted for 6 months beginning in December 2004 and ending in May 2005. A convenience sample was formed of patients with type 2 diabetes mellitus, attending the $\mathrm{CAD}$ in Colón, Matanzas province, who responded to a call for participants and who met the inclusion criteria established in the research protocol. The group consisted of 16 adults: 3 men $(18.8 \%)$ and 13 women (81.3\%), average age 60 years (range: 44-73 years) and 9-31 years disease evolution. All were being treated with insulin (670 units/day total; average per capita: 42.4 units/day; 0.61 units/kg body weight) and 2 patients also used glibenclamide (6 tablets/day total; $0.2 \mathrm{mg} / \mathrm{kg}$ body weight).

Inclusion criteria Confirmed diagnosis of type 2 diabetes mellitus with poor glucide metabolism control (glycosylated hemoglobin, $\mathrm{HbA} 1>8.5 \%$ ); voluntary participation with informed consent; pharmacological treatment with insulin and hypo- or normo-glycemic tablets, or both; aged 20-75 years; residence near the CAD or with transportation; completion of a macrobiotic diet therapy course, consisting of 28 hours of practical cooking classes (selection of food items, amounts, combinations, proportions, eating frequency, handling, cooking methods and food preservation) and 28 hours of theory (principles underlying the diet and its nutritional and therapeutic potential). The course was given during the pre-intervention period when patients were being evaluated to determine if they complied with the remaining inclusion criteria established in the protocol.

Exclusion criteria Presence of other diseases or use of drugs interfering with carbohydrate metabolism, invalidating diseases (terminal stage disease, mental impairment, etc.), addictions, hemoglobin $<10 \mathrm{mg} / \mathrm{dl}$, or body mass index $(\mathrm{BMI})<18.5$.

Exit criteria Intolerance or non-acceptance of the diet, hemoglobin $<10 \mathrm{mg} / \mathrm{dl}$, BMl $<18.5$, persistent signs or symptoms of nutritional deficiencies or excesses, interruption of the diet (more than 2 days absence from the dining hall in one month), failure to participate in medical evaluations established in the protocol, voluntary abandonment of the study, appearance of other diseases or complications requiring hospitalization or medications interfering with study results.

Adverse events Any medical event occurring during the intervention that may or may not be attributed to the diet. Anemia, low weight, and signs and symptoms of nutritional deficiencies or excesses were considered events possibly attributable to the diet.

Ethical considerations The study was conducted according to the Helsinki Declaration.[18] All participants were informed of the procedures and possible drawbacks of the study, and written informed consent was obtained. The Scientific Council and the Ethics Committee of the Matanzas Medical School approved the study protocol.

Diet Total volume of the Ma-Pi 2 diet consisted of $40-50 \%$ whole grains (rice, millet and barley), $30-40 \%$ vegetables (carrots, kale, cabbage, broccoli, chicory, onions, red and white radish, parsley), and $8 \%$ legumes (adzuki beans, chickpeas, lentils, black beans), plus gomashio (roasted ground sesame seeds with unrefined sea salt), fermented products (miso, tamari, umeboshi) and seaweeds (kombu, wakame, nori). Bancha tea (tannin-free green tea) was the main source of liquid.

Food intake was measured using the weight method for 7 consecutive days in the 2nd and 4th months of the intervention. Average nutritional content was calculated using internationally recognized chemical composition charts for food[19-22] and was compared with daily intake allowances recommended by the Joint FAO/WHO Expert Consultation group and the US Academy of Sciences Food and Nutrition Board.[23,24] Recommended intake of protein, fat and carbohydrates was set at $15 \%, 20 \%$ and $65 \%$ of total energy, respectively. Tolerable upper intake levels of vitamins and minerals were established. The protein amino acid score was assessed using the adult amino acid requirements proposed by Millward,[25] corrected for $80 \%$ digestibility, since all proteins were vegetable.

Statistical data and methods Anthropometric measurements and blood samples were taken at onset and termination of the intervention ( 0 and 6 months, respectively). All participants' body weight, height, waist and hip circumferences, and skin folds (biceps, triceps, subscapular and suprailiac) were measured.[26] Durnin/Womersly equations were used to estimate body density. [27] Percentage of body fat was calculated using Siri's equation. [28] All measurements were made by specialized technicians from the Nutrition and Food Hygiene Institute (INHA, its Spanish acronym). 
The following 12-hour fasting blood tests were also performed: total cholesterol, HDL cholesterol, LDL cholesterol, triglycerides, glucose, glycosylated hemoglobin ( $\mathrm{HbA1}$ ), C-peptide, hemoglobin, total proteins, albumin and creatinin. Glucose, lipids, and other hematologic and biochemical variables were measured using internationally established techniques,[29-31] in the Faustino Pérez Provincial Hospital laboratory in Matanzas. A Hitachi 902 Automatic Analyzer (Roche Diagnostics $\mathrm{GmbH}$, Germany) was used with HELFA-Diagnostics commercial kits (Cuba).

C-peptide and HbA1 were measured in the National Endocrinology Institute laboratory in Havana. Solid-phase radioimmunoassay (Schering AG CIS Bio International, France) was used to measure C-peptide concentrations (normal values 1.07$3.51 \mathrm{ng} / \mathrm{ml}$ ), and the ion-exchange resin separation method was used to determine HbA1 levels (Human Gesellschaft für Biochemic und Diagnostic $\mathrm{GmbH}$, Germany) (normal values 4.5-7.0\%). Diagnostic cut-off points for metabolic control were set as follows: good, 4.5-7.5\%; acceptable, 7.5\%-8.5\%; poor, $>8.5 \%$.[32] Cardiovascular risk was estimated according to serum lipid values.[33]

Quantitative variables at 0 and 6 months were compared, and results were described using stadigraphs, mean and median. Student's t-test and the Wilcoxon test were used for comparison of matched pairs with a significance level of $p \leq 0.05$.

Procedure A logbook was specifically designed for this intervention, and data on each patient was collected and recorded daily for the first month, every other day during the second month, and twice a week for the remaining months. Patient evolution data included clinical signs and symptoms, heart rate, blood pressure, glycemic profile, tolerance and acceptance of the diet, adverse events, and amounts of medication used. Body weight was recorded monthly. Capillary glycemic profiles were evaluated regularly using a glucometer (Roche, USA).

As glycemia values declined, hypoglycemic medicine doses were reduced.

Patients received full food service daily (breakfast, lunch, dinner and snacks) in the CAD macrobiotic dining hall. Food was prepared by expert macrobiotic cooks from UPM. Patients could have more than one serving as long as proportions of grains, vegetables and legumes were maintained.

\section{RESULTS}

The diet supplied adequate energy and was highly filling, low in energy density and high in complex carbohydrates (Table 1). Total energy composition was $12 \%$ protein, $16 \%$ fat and $72 \%$ carbohydrate.

All nutrients fulfilled $>90 \%$ of recommended daily allowances, except vitamin B12, which met only $23 \%$, well below the recommended amount. Nutritional content of dietary fiber, vitamin $A$ from $\beta$-carotenes, folates, vitamin $C$, thiamine, pyridoxine, niacin, manganese and magnesium was notably high (Table 1). Despite the absence of dairy and animal products in the diet, intake of calcium and iron was adequate. The amino acid score was $99 \%$, corrected for $80 \%$ digestibility, with methionine + cysteine as the limiting amino acids, indicating adequate proportions of grains, legumes and sesame seeds in the protein mix.
Table 1: Average Daily Nutritional Content, Ma-Pi 2 Diet vs. Recommended Intake

\begin{tabular}{|c|c|c|}
\hline \multirow{2}{*}{ Nutrient } & \multicolumn{2}{|c|}{ Average Daily Intake Per Person } \\
\hline & Ma-Pi 2 Diet & Recommendation \\
\hline Energy (kcal) & 2202 & 2000 \\
\hline Protein $(\mathrm{g})$ & 66 & 75 \\
\hline -Tryptophan* & 13 & 7 \\
\hline -Threonine* & 35 & 29 \\
\hline -Isoleucine* & 41 & 34 \\
\hline -Leucine* & 73 & 50 \\
\hline -Lysine* & 42 & 35 \\
\hline -Methionine + Cysteine* & 34 & 31 \\
\hline -Phenylalanine + Tyrosine* & 78 & 38 \\
\hline -Valine* & 50 & 26 \\
\hline Total fat (g) & 39 & 44 \\
\hline Carbohydrates (g) & 396 & 325 \\
\hline Fiber (g) & 55 & $30-55$ \\
\hline Vitamin C (mg) & 153 & $45-2000$ \\
\hline Folic acid $(\mu \mathrm{g})$ & 781 & $400-1000$ \\
\hline Vitamin B1 (mg) & 3.50 & 1.2-NA \\
\hline Vitamin B2 (mg) & 1.31 & 1.3-NA \\
\hline Vitamin B6 (mg) & 5.46 & 1.4-NA \\
\hline Niacin (mg) & 25 & $16-35$ \\
\hline Vitamin B12 $(\mu \mathrm{g})$ & 0.45 & 2.0-NA \\
\hline Vitamin E (mg) & 9.0 & $9-1000$ \\
\hline Vitamin A $(\mu \mathrm{g})$ & 3376 & $550-3000^{* *}$ \\
\hline Potassium (mg) & 3756 & $2000-3500$ \\
\hline Manganese (mg) & 16.0 & $2-11$ \\
\hline Iron (mg) & 24.0 & $18-53$ \\
\hline Calcium (mg) & 978 & $750-2500$ \\
\hline Phosphorus (mg) & 1632 & $800-4000$ \\
\hline Zinc (mg) & 15.2 & $12-40$ \\
\hline Magnesium (mg) & 754 & $250-350^{\star * *}$ \\
\hline Sodium (mg) & 1724 & $500-2300$ \\
\hline
\end{tabular}

\section{NA: Data not available}

${ }^{*} \mathrm{mg}$ of amino acid per gram of protein

** preformed vitamin A only

*** tablets only

Source: Study data

The only adverse event observed during the intervention was slight carotinemia when carrots and green leaf vegetables were more abundant. No participants abandoned the study, although the diet differs greatly from most Cubans' tastes and preferences in food [34] and was hard to accept at first, particularly for participants unaccustomed to eating vegetables. They adapted quickly, however, and acceptability noticeably improved.

After 6 months of Ma-Pi 2 dietary intervention, statistically significant reductions in mean body weight $(9.0 \%)$, BMI $(9.1 \%)$, waist circumference $(6.7 \%)$, hip circumference $(5.1 \%)$, skin folds (triceps $24.2 \%$, subscapular $24.1 \%$, suprailiac $28.0 \%$ ) and body fat $(9.7 \%)$ were found, as well as a statistically significant increase lean body mass $(6.9 \%)$ (Table 2 ).

Changes in mean levels of total protein, albumin and creatinin were not statistically significant, while mean hemoglobin and lipid variables all showed statistically significant changes. Reductions in higher hemoglobin values accounted for the $7.4 \%$ drop in mean hemoglobin $(10.1 \mathrm{~g} / \mathrm{dl}-19.6 \mathrm{~g} / \mathrm{dl}$ at onset vs $11.2 \mathrm{~g} / \mathrm{dl}-13.6 \mathrm{~g} / \mathrm{dl}$ at termination). Total cholesterol, LDL cholesterol and triglycerides decreased $16.4 \%, 22.7 \%$ and $37.0 \%$, respectively, while HDL 
Table 2: Physical Variables in Diabetic Patients at Onset and Termination of 6-Month Ma-Pi 2 Dietary Intervention

\begin{tabular}{|l|c|c|c|c|c|}
\multirow{2}{*}{ Variable } & \multicolumn{2}{|c|}{ Onset } & \multicolumn{2}{c|}{$\mathbf{6}$ months } & \multirow{2}{*}{ p } \\
\cline { 2 - 5 } & Mean & Median & Mean & Median & \multirow{2}{*}{ Weight (kg) } \\
\hline W.28 & 69.40 & 63.03 & 59.90 & $0.001470^{*}$ \\
\hline Waist Circumference (cm) & 89.79 & 86.30 & 83.75 & 80.50 & $0.004101^{*}$ \\
\hline Hip Circumference (cm) & 98.93 & 96.55 & 93.86 & 92.60 & $0.003478^{*}$ \\
\hline Triceps Skin Fold (mm) & 26.81 & 23.00 & 20.31 & 21.50 & $0.000317^{*}$ \\
\hline Subscapular Skin Fold (mm) & 32.88 & 30.00 & 24.94 & 25.50 & $0.000439^{*}$ \\
\hline Biceps Skin Fold (mm) & 16.19 & 14.50 & 14.63 & 14.00 & 0.1313 \\
\hline Suprailiac Skin Fold (mm) & 31.88 & 28.00 & 22.94 & 22.00 & $0.001511^{*}$ \\
\hline BMI (kg/m²) & 27.97 & 28.41 & 25.43 & 25.10 & $0.000255^{*}$ \\
\hline Fat (\%) & 41.82 & 41.51 & 37.78 & 39.54 & $0.000723^{*}$ \\
\hline Lean Body Mass (\%) & 58.18 & 58.49 & 62.22 & 60.46 & $0.000481^{*}$
\end{tabular}

* $p<0.05$

Source: Study data

Table 3: Hematologic and Biochemical Variables in Diabetic Patients at Onset and Termination of 6-Month Ma-Pi 2 Dietary Intervention

\begin{tabular}{|c|c|c|c|c|c|}
\hline \multirow{2}{*}{ Variable } & \multicolumn{2}{|c|}{ Onset } & \multicolumn{2}{|c|}{6 months } & \multirow[b]{2}{*}{$\mathbf{p}$} \\
\hline & Mean & Median & Mean & Median & \\
\hline Hemoglobin (g/dl) & 13.38 & 13.40 & 12.39 & 12.05 & $0.02329 *$ \\
\hline Total proteins (g/l) & 77.73 & 77.45 & 74.79 & 76.15 & 0.2979 \\
\hline Albumin (g/l) & 41.26 & 41.00 & 41.57 & 41.00 & 0.6601 \\
\hline Creatinin $(\mu \mathrm{mol} / \mathrm{l})$ & 62.69 & 64.00 & 63.06 & 59.00 & 0.8908 \\
\hline Total cholesterol ( $\mathrm{mmol} / \mathrm{l})$ & 5.37 & 5.46 & 4.49 & 4.55 & $0.002279^{*}$ \\
\hline HDL cholesterol $(\mathrm{mmol} / \mathrm{l})$ & 0.45 & 0.46 & 0.89 & 0.85 & $0.000480^{*}$ \\
\hline LDL cholesterol (mmol/l) & 3.52 & 3.90 & 2.72 & 2.81 & $0.002145^{*}$ \\
\hline Triglycerides (mmol/l) & 2.97 & 2.40 & 1.87 & 1.91 & $0.001092^{*}$ \\
\hline Glycemia (mmol/l) & 14.03 & 12.55 & 5.08 & 4.70 & $0.000214^{*}$ \\
\hline $\mathrm{HbA} 1(\%)$ & 12.60 & 12.00 & 5.73 & 5.70 & $0.000481^{*}$ \\
\hline C-peptide (ng/ml) & 2.15 & 2.21 & 2.43 & 2.47 & 0.3052 \\
\hline
\end{tabular}

$* p<0.05$

Source: Study data

cholesterol increased $97.8 \%$, doubling its onset value. Lipid ratios also improved: Total cholesterol/HDL cholesterol dropped $57.9 \%$, from $11.9 \mathrm{mmol} / \mathrm{l}$ to $5.0 \mathrm{mmol} / \mathrm{l}$, and LDL/HDL decreased $60.3 \%$, from $7.8 \mathrm{mmol} / \mathrm{l}$ to $3.1 \mathrm{mmol} / \mathrm{l}$ (Table 3 ).

The $63.8 \%$ reduction in mean glycemia and $54.5 \%$ reduction in $\mathrm{HbA} 1$ were also statistically significant, although the $13 \%$ increase in C-peptide was not (Table 3). HbA1 values at termination (mean value $5.73 \% ; 4.5 \%-7.5 \%$ ) indicated that all participants had achieved good control of glucide metabolism, compared to a mean of $12.60 \%(10 \%-16 \%)$ at onset.

Risk of cardiovascular disease associated with lipoprotein and triglyceride levels decreased notably in almost all patients (Table 4). At intervention onset, only 5 patients $(31.3 \%)$ had desirable total cholesterol $(\leq 5.18 \mathrm{mmol} / 1)$ and 3 patients $(18.8 \%)$ were classified as high risk $(\geq 6.2 \mathrm{mmol} / 1)$. Six months later, at termination, 13 patients $(81.3 \%)$ had achieved desirable cholesterol levels and zero participants were considered high risk.

At termination of the intervention, insulin administration had been eliminated in all patients, and 12 patients (75.0\%) were receiving the Ma-Pi 2 macrobiotic diet as their only therapy. Overall glib- enclamide use increased from 6 to 15 tablets daily $(0.76$ $\mathrm{mg} / \mathrm{kg}$ weight), since 4 patients initiated glibenclamide therapy when they stopped taking insulin.

\section{DISCUSSION}

Therapeutic diets for diabetes mellitus all have the same goals: adequate body weight, normal glycemia and lipid values, reduced oxidative stress, and preserved or improved endogenous insulin secretion.[8] Results of this study show that the Ma-Pi 2 diet intervention met these objectives. Preliminary assessment of its nutritional characteristics suggest that this macrobiotic diet fully meets functional requirements; however, further research on its physiological, biochemical and metabolic mechanisms is required to confirm that claim.

Results of this study also support evidence that a diet rich in fiber, complex carbohydrates, whole grains and legumes improves glycemia control, lowers insulin requirements, slows glucose absorption, increases peripheral tissue sensitivity to insulin, reduces cholesterol and serum triglyceride levels, controls body weight and lowers blood pressure.[35]

Causes of decreased insulin secretion in type 2 diabetic patients have not been fully determined. Amyloid protein deposits in pancreatic ß-cells, as well as glucotoxicity and lipotoxicity resulting from elevated concentrations of glucose and circulating free fatty acids, are among factors involved.[36] The beneficial effects of the Ma-Pi 2 diet observed in the study may be partially attributed to the high content of complex carbohydrates, total and soluble fiber, and resistant starch, resulting in high satiety and therefore higher energy intake without negative metabolic effects. Large quantities of chicory and onion used in the Ma-Pi diet are rich sources of inulin, a soluble dietary fiber, shown to have a marked hypoglycemic effect in obese and dyslipidemic individuals.[37] The botanical structure (structural quality) of whole grains in the diet may also have a direct effect on glucose and insulin metabolism.[38]

The low fat content of the Ma-Pi 2 diet may also contribute to improved anthropometric and glucide and lipid metabolism indicators. Low fat diets encourage weight loss, whereas high fat diets are strongly associated with obesity, glucose intolerance and increased insulin resistance.[11] Additionally, adipose tissue mass is directly related to insulin resistance as well as peripheral and central sensitivity to insulin and leptin.[39] In the present study, weight loss and reduction in total body fat and abdominal fat with preservation of lean body mass were among the first effects of the diet observed in participants.

Other nutrients contained in substantial quantities in the Ma-Pi 2 diet also may have contributed to the beneficial effects found in this intervention. Research has shown, for example, that magnesium and manganese are essential to metabolic control of diabetes mellitus.[40,41]

The Ma-Pi 2 diet also resulted in statistically significant control of serum lipids, indicating recovery of energy homeostasis and 
Table 4: Lipoproteins and Cardiovascular Risk in Diabetic Patients at Onset and Termination of 6-Month Ma-Pi 2 Dietary Intervention

\begin{tabular}{|c|c|c|c|c|c|c|}
\hline \multirow{2}{*}{ Variable } & \multirow{2}{*}{\multicolumn{2}{|c|}{ Cut-off Values }} & \multicolumn{2}{|c|}{ Onset } & \multicolumn{2}{|c|}{6 months } \\
\hline & & & $n$ & $\%$ & & $\%$ \\
\hline \multirow{3}{*}{ Total Cholesterol $(\mathrm{mmol} / \mathrm{l})$} & Desirable & $\leq 5.2$ & 5 & 31.25 & 13 & 81.25 \\
\hline & Borderline & $5.2-6.19$ & 8 & 50.00 & 3 & 18.75 \\
\hline & High & $\geq 6.20$ & 3 & 18.75 & 0 & 0 \\
\hline \multirow{3}{*}{ LDL Cholesterol (mmol/l) } & Acceptable & $\leq 3.39$ & 7 & 43.75 & 14 & 87.50 \\
\hline & Borderline & $3.4-4.1$ & 4 & 25.00 & 1 & 6.25 \\
\hline & High & $\geq 4.12$ & 5 & 31.25 & 1 & 6.25 \\
\hline \multirow{3}{*}{ HDL Cholesterol (mmol/l) } & Desirable & $>1.6$ & 0 & 0 & 5 & 31.25 \\
\hline & Acceptable & $1.0-1.6$ & 0 & 0 & 5 & 31.25 \\
\hline & Undesirable & $\leq 0.9$ & 16 & 100.00 & 6 & 37.50 \\
\hline \multirow{3}{*}{ Triglycerides (mmol/l) } & Acceptable & $\leq 2.29$ & 5 & 31.25 & 15 & 93.75 \\
\hline & High & $2.3-5.6$ & 10 & 62.50 & 1 & 6.25 \\
\hline & Very high & $\geq 5.65$ & 1 & 6.25 & 0 & 0 \\
\hline
\end{tabular}

Source: Study data

greater protection against cardiovascular and other complications of diabetes. High levels of total and LDL cholesterol, along with low levels of HDL cholesterol, are atherogenic risk factors associated with premature coronary disease and diabetic macroangiopathy.[42]

Statistically significant reductions in glycemia and glycosylated hemoglobin in this study indicate the Ma-Pi 2 diet's positive influence on carbohydrate metabolism control. Interventions that improve glycemic control, reflected by glycosylated hemoglobin, are associated with reduced risk of diabetic complications. Hyperglycemic intake is a major cause of microvascular complications; reducing glycemia levels through diet or other therapeutic agents can therefore have long-term benefits.[43]

Pancreatic ß-cell failure is common in type 1 and type 2 diabetes mellitus, although the responsible mechanism may be different. Restoring or protecting their function is a desirable therapeutic effect. C-peptide determination under standardized conditions is a sensitive, well-accepted and clinically validated indicator of ß-cell function, and moderate increases in this indicator may represent potential for clinical improvement.[43] The $13 \%$ increase in C-peptide levels in this study was not significant, suggesting that more than 6 months of sustained diet therapy may be necessary to improve pancreatic ß-cell function. Elimination of insulin use in all patients in this study, however, may indicate some recovery of pancreatic function, lower peripheral resistance to insulin or lower insulin demand.

One of the main effects of the Ma-Pi 2 diet may be its potential to supply alkalis to metabolism. The amount of acid residue generated by the typical Western diet (mainly sulfuric amino acids contained in animal proteins) is currently under debate. It may be argued that such residue surpasses the capacity of homeostatic mechanisms, producing an increase in blood acidification, resulting in lowered plasma bicarbonate concentration.[44] One effect of this low level chronic acidosis may be increased insulin resistance.[45] Epidemiological studies reported in the literature also suggest that sustained high protein intake is associated with higher incidence of type 2 diabetes mellitus.[44]

A strong association has also been shown between diabetes mellitus and oxidative stress. It has been suggested that high oxidative stress due to hyperglycemia leads to diabetic complications and may be a major cause of cell damage.[46] Nutrients such as vitamins $E$ and $C, \beta$-carotene and other phytochemical compounds with antioxidant effects contained in the whole grains, vegetables, legumes, green tea and fermented soy products used in the Ma$\mathrm{Pi}$ diet may therefore have influenced the results of the intervention.[14,47]

The only negative effect of the diet observed during the intervention was the vitamin B12 deficiency, resulting from the lack of animal foods in the Ma-Pi 2 diet and indicating a potential long-term risk. Given the size and type of sample studied, results cannot be extrapolated to the rest of the diabetic population, nor can the diet be recommended for longer than 6 months, the maximum period for which its nutritional safety in diabetic patients has been demonstrated.[15,16]

Dietary intervention studies are difficult, particularly those designed to assess therapeutic effects. Research involving macrobiotic diets has the added drawback of rejection by most of the medical and scientific community, which considers them too restrictive and even elitist, because they prioritize organic foods and use a range of products uncommon in Western diets.

The results of this and related studies[14-17] provide important preliminary data and indicate that further research is warranted to explain the mechanisms influencing the diet's therapeutic potential and to establish recommendations for its use. In Cuba, we have proposed conducting a clinical trial using a control group receiving the standard diet approved for diabetics by the Ministry of Public Health.

An important aspect to consider is acceptability, independent of the diet's therapeutic potential. In the present study, availability of the diet was a major factor, since patients received all meals fully prepared and without cost. The objectives of the course required for inclusion in the study were to motivate participants to stick to the diet during the intervention, enable them to prepare food themselves if they were absent from the dining hall, and continue the diet as much as possible on their own, following termination of the intervention. After a period of adaptation, acceptability was high. Further research on patient behavior is needed, however, to assess acceptance and continuation with the diet outside the intervention setting.

Although economic factors were not among the objectives of this study, it is worth noting that the cost of the imported products used (miso, tamari, seaweeds and green tea) was about 0.20 Euros per day per patient, according to the Ministry of the Food Industry (MINAL, its Spanish acronym), which procured the items.

This suggests that the cost of the Ma-Pi 2 diet per person may be lower than that of the standard recommended diet for diabetics in Cuba, consisting of several daily portions of dairy products, meat, eggs, sausages, fruits, fat and root vegetables, apart from vegetables, legumes and grains consumed in both diets. Studies are also recommended to compare actual costs of diabetic patient care taking into account type of diet, medication, health care utilization, productivity, absenteeism and other factors. 


\section{Original Scientific Articles}

The Finlay Institute is actively working across sectors in Cuba to improve availability of Ma-Pi diet ingredients in order to fulfill an ethical obligation to study participants who benefited from the intervention, help them and other diabetics follow the diet independently, meet rising consumer demand and supply its own programs. Through collaboration between the Ministry of Agriculture, the National Urban Agriculture Movement and the Institute for Rice Research, production of whole grains (particularly brown rice and millet), vegetables and oleaginous seeds is being expanded throughout the country.

\section{CONCLUSIONS}

Results of the 6-month intervention using the Ma-Pi 2 macrobiotic diet in adults with type 2 diabetes mellitus suggest this diet may be a good alternative for comprehensive treatment of diabetes mellitus in Cuba. Further studies are recommended, specifically a clinical trial using a control group receiving the standard diet recommended by the Cuban Ministry of Public Health. Broader multi-sector collaboration is also needed to increase availability and accessibility of whole grains and other products essential to achieving the nutrient content potentially influencing the beneficial effects of the Ma-Pi 2 diet. $-1 /$ -

\section{REFERENCES}

1. Federación Internacional de la Diabetes. Diabetes Atlas. 3rd ed.; 2006

2. Wild S, Roglic G, Green A, Sicree R, King H Global prevalence of diabetes: estimates for 2000 and projections for 2030. Diabetes Care. 2004;27(5):1047-53.

3. Pan American Health Organization/World Health Organization. Estrategia regional y plan de acción para un enfoque integrado sobre la prevención y el control de las enfermedades crónicas, incluyendo el régimen alimentario, la actividad física y la salud. Resolución CD47R9 del $47^{\circ}$ Consejo Directivo, $58^{a}$ Sesión del Comité Regional, Washington, DC, 2006 Sep 25-29.

4. Zimmet P, Alberti KG, Shaw J. Global and societal implications of the diabetes epidemic. Nature. 2001 Dec 13:414(6865):782-7. Review.

5. Boyle JP, Honeycutt AA, Narayan KM, Hoerger TJ, Geiss LS, Chen $H$, et al. Projection of diabetes burden through 2050: impact of changing demography and disease prevalence in the U.S. Diabetes Care. 2001 Nov;24(11):1936-40.

6. The Economic Impact of Diabetes. In: Diabetes Atlas. 3rd ed. Brussels: International Diabetes Federation; 2006.

7. American Diabetes Association. Evidence-based nutrition principles and recommendations for the treatment and prevention of diabetes and related complications. Diabetes Care. 2002 Jan;25(1):202-12.

8. The Prevention of Diabetes Mellitus and Its Complications. Geneva: World Health Organization; 2008.

9. American Diabetes Association. Nutrition recommendations and interventions for diabetes: a position statement of the American Diabetes Association. Diabetes Care. 2008 Jan;31 Suppl 1:S61-78.

10. Willett WC, Koplan JP, Nugent R, Dusenbury C, Puska P, Gaziano TA. Prevention of Chronic Disease by Means of Diet and Lifestyle Changes. In: Jamison DT, et al, editors. Disease Control Priorities in Developing Countries. 2nd ed. New York: Oxford University Press; 2006. p. 833-50.

11. Willett W, Manson J, Liu S. Glycemix index, glucemix load, and risk of type 2 diabetes. Am J Clin Nutr. 2002 Jul;76(1):274S-80S.

12. Ohsawa G. Le zen macrobiotique ou l'art du rajeunissement et de la longévité. Paris: Librairie Philosophique J Vrin; 2004

13. Pianesi M. Las 5 dietas Ma-Pi. Macerata (IT): L'Chi; 2007.

14. Porrata C, Hernández M, Abuín A, Campa C, Pianesi M. Caracterización y evaluación nutricional de las dietas macrobióticas Ma-Pi. Rev Cubana Investig Biomed. 2008;27(3-4):1-36.

15. Porrata $C$, Hernández $M$, Castro $D$, Naranjo $M$, Vilá R, Díaz ME, et al. Security and nutritional value of macrobiotic diet. The Cuban experience. Proceedings of Intrafood-2005; 2005 Oct 25-28; Valencia, Spain. Spain: Elsevier; 2005.
16. Porrata C, Abuín A, Morales A, Vilá R, Hernández $\mathrm{M}$, Menéndez $\mathrm{J}$, et al. Efecto terapéutico de la dieta macrobiótica Ma-Pi 2 en 25 adultos con diabetes mellitus tipo 2. Rev Cubana Invest Biomed. 2007;26(2).

17. Bhumisawasdi J, Vanna O, Surinpang N. The self-reliant system for alternative care of diabetes mellitus patients. Experiences macrobiotic management in Thai province. J Med Thai. 2006;89(12):2104-15.

18. Declaración de Helsinki de la Asamblea Médica Mundial. Principios éticos para las investigaciones médicas en seres humanos. 52a Asamblea General [monograph on the Internet]. Escocia: Asamblea Médica Mundial; 2000 [cited 2007 Feb 22]. Available from: http://www.upo.es/general/ investigar/otri/otri docu/pn/Decl Helsinki.pdf

19. U.S Department of Agriculture, Agricultural Research Service. 2004 [homepage on the Internet]. USDA National Nutrient Database for Standard reference, Release 17. Nutrient Data Laboratory Home Page. Washington: USDA; (C)2008 [updated 2008 Jan 28; cited 2008 Feb 25]. Available from: http://www.ars.usda.gov/Services/docs.htm?docid=5717

20. Hagiwara K. Standard Tables of Food Composition in Japan Fifth Revised Edition. J Integr Study Diet Habits. 2001;12(2):86-9.

21. Banca Dati di composizione degli alimenti per studi epidemiologici in Italia [database on the Internet]. Milano: Istituto Europeo di Oncologia. C1998 [cited 2008 Feb 22]. Available from: http:// www.ieo.it/bda2008/homepage.aspx

22. Banca dati interativa di Composizione degli alimenti, INRAN [database on the Internet]. Italy: Istituto Nazionale di Recerca per gli alimenti e la Nutrizione, [updated 2000; [cited 2008 Feb 22]. Available from: http://www.inran.it/servizi_cittadino/per_saperne_di_piu/tabelle_composizione_ alimenti

23. Manual on Human Nutritional Requirements. Report of a Joint FAO/WHO Expert Consultation. Rome: FAO/WHO; 2002.

24. Panel on Macronutrients, Subcommittees on Upper Reference Levels of Nutrients and Interpretation and Uses of Dietary Reference Intakes, and the Standing Committee on the Scientific Evaluation of Dietary Reference Intakes, Food and Nutrition Board, Institute of Medicine of the National Academies. Dietary Reference Intakes for Energy, Carbohydrate, Fiber, Fat, Fatty Acids, Cholesterol, Protein, and Amino Acids. Washington, DC: National Academies Press; 2005.

25. Sarwar G. Analytical issues related to food composition and protein quality. In: Protein and Amino Acid Requirements in Human Nutrition. Report of a Joint WHO/FAO/UNU Expert Consultation. WHO Technical Report Series 935. Geneva: WHO; 2007.

26. Lohman TG, Roche AF, Martorell R. Anthropometric Standardization Reference Man- ual. Illinois: Human Kinetics Books Champaign; 1988.

27. Durnin JVGA, Womersly J. Body fat assessed from total body density and its estimation from skinfolds thickness: measurements on 481 men and women aged from 16 to 72 years. Br J Nutr. 1974 Jul;32(1):72-97.

28. Siri WE. Body composition from fluid spaces and density. Analysis of methods. In: Techniques for measuring body composition. National Research Council, Washington DC; 1961. p. 223-44.

29. Burtis CA, Ashwood ER, Bruns DE, editors. In: Tietz Textbook of Clinical Chemistry and Molecular Diagnostics. 4th ed. St. Louis (US): Elsevier Saunders; 2006

30. Burstein M, Scholnick HR, Morfin R. Rapid method for the isolation of lipoproteins from human serum by precipitation with polyanions. J Lipid Res. 1970 Nov;11(6):583-95.

31. Lopes-Virella MF, Stone P, Ellis S, Colwell JA Cholesterol determination in high density lipoproteins separated by three different methods. Clin Chem. 1977 May;23(5):882-4.

32. American Diabetes Association. Clinical practice recommendations. Diabetes Care. 2000;23 Suppl 1:S32-60.

33. Third Report of the National Cholesterol Education Program Expert Panel on Detection, Evaluation, and Treatment of High Blood Cholesterol in Adults (Adult Treatment Panel III). Bethesda (US): National Institutes of Health; 2002.

34. Porrata C. Cubans' deadly diet: a wakeup call. MEDICC Review. 2008 Spring;10(2):52.

35. Connor H, Annan F, Bunn E, Frost G, McGouth $\mathrm{N}$, Sarwar $\mathrm{T}$, et al. The implementation of nutritional advice for people with diabetes. Diabetes Med. 2003 Oct;20(10):786-807.

36. Guillausseau PJ, Meas T, Virally M, Laloi-Michelin M, Médeau V, Kevorkian JP. Abnormalities in insulin secretion in type 2 diabetes mellitus. Diabetes Metab. 2008;34 Suppl 2:S43-8.

37. Beylot M. Effects of inulin-type fructans on lipid metabolism in man and in animal models. $\mathrm{Br} \mathrm{J}$ Nutr. 2005;93 Suppl 1:S163-8.

38. Slavin JL. Plausible mechanism for the protectiveness of whole grains. Am J Clin Nutr. 1999;70 Suppl:S459-63.

39. Schwartz MW. Porte D Jr. Diabetes, obesity and the brain. Science. 2005 Jan 21;307(5708):375-9.

40. Sales $\mathrm{CH}$, Pedrosa $\mathrm{L}$ de $\mathrm{F}$. Magnesium and diabetes mellitus: their relation. Clin Nutr. 2006 Aug;25(4):554-62. Epub 2006 May 11.

41. Lee SJ, Choi MG. Association of manganese superoxide dismutase gene polymorphism (V16A) with diabetic macular edema in Korean type 2 diabetic patients. Metabolism. 2006 Dec;55(12):1681-8.

42. Bellomo A, Mancinella M, Troisi G, Ettorre E, Marigliano V. Diabetes and metabolic syndrome (MS). Arch Gerontol Geriatr. 2007;44 Suppl:S61-7. 
43. Palmer JP, Fleming GA, Greenbaum CJ, Herold $K C$, Jansa LD, Kolb H, et al. C-Peptide is the appropriate outcome measure for type 1 diabetes clinical trials to preserve $\beta$-cell function: report of an ADA workshop, 21-22 October 2001. Diabetes. 2004 Jan;53(1):250-64.

44. Promintzer M, Krebs M. Effects of dietary protein on glucose homeostasis. Curr Opin Clin Nutr Metab Care. 2006 Jul;9(4):463-8.

45. Demigné C, Sabboh H, Puel C, Rémésy C, Coxam V. Organic anions and potassium salts in nutrition and metabolism. Nutr Res Rev. 2004 Dec;17(2):249-58.

46. O'Driscoll L, Gammell P, Clynes M. Mechanisms associated with loss of glucose responsiveness in beta cells. Transplant Proc. 2004 May;36(4):1159-62.

47. González Montesino D. Capacidad antioxidante y aporte de polifenoles de las dietas macrobióticas Ma-Pi implementadas en el Instituto Finlay [master's thesis]. Havana (CU): University of Havana; 2009.

\section{THE AUTHORS}

Carmen Porrata Maury (Corresponding author: cporrata@finlay.edu.cu). Physiologist. Head of the Ma-Pi Macrobiotic Group, Finlay Institute, Havana, Cuba.
Julio Sánchez Cruz, endocrinologist, Diabetic Care Center, Colón, Matanzas, Cuba.

Violeta Correa Corrales, family medicine specialist, Diabetic Care Center, Colón, Matanzas, Cuba.

Alfredo Abuín Landín, biochemist, Matanzas Medical School, Matanzas, Cuba.

Manuel Hernández-Triana, biochemist. Head of the Biochemistry and Physiology Department, Nutrition and Food Hygiene Institute, Havana, Cuba.

Raúl Vilá Dacosta-Calheiros, family medicine specialist, Ma-Pi Macrobiotic Group, Finlay Institute, Havana, Cuba.

María Elena Díaz Sánchez, anthropologist. Head of the Anthropology Laboratory, Nutrition and Food Hygiene Institute, Havana, Cuba.
Mayelín Mirabal Sosa, mathematician, Clinical Trials Department, Finlay Institute, Havana, Cuba.

Eduardo Cabrera Rode, biologist, National Endocrinology Institute, Havana, Cuba.

Concepción Campa Huergo, pharmacist and biochemist. President and General Director, Finlay Institute, Havana, Cuba.

Mario Pianesi, President and founder, Un Punto Macrobiótico International Association, Italy.

Submitted: March 19, 2009

Approved for publication: September 27, 2009 